\title{
The Survey of the Main Trends of the ERP Applications in the Czech Republic and their Business Effects
}

\author{
Basl Josef, Pour Jan and Simkova Eva \\ University of Economics, Prague, W.Churchill Sq. 4, 13067 Prague, Czech Republic \\ basl@vse.cz pour@vse.cz simkova@logos.cz
}

\begin{abstract}
The article deals with the analysis of the ERP market in the Czech Republic provided annually from 1993 (approx. 50 - 60 products each year). The main attention has been put on the functionality of the ERP but the scope is extended to the expected trends, SWOT analysis of the ERP products and market potential in the Czech Republic. The level of penetration of different ICT applications in the Czech companies and (mainly ERP, SCM,) and trends of future areas of application development are also included. Second part of the paper is oriented towards quality of enterprise informatics and its effect on the growth of competitiveness, increased performance related to enterprise management including analysis and planning of comprehensive objectives. All information are results of own research.
\end{abstract}

Keywords: Information systems, Enterprise information systems, ERP, Business effects of ICT

\section{INFORMATION AND COMMUNICATION TECHNOLOGY (ICT) DEVELOPMENT}

Czech companies have invested millions of euros in enterprise information systems (mostly in ERP - Enterprise Resource Planning) with the objective to achieve the important business aims - complete enterprise integration. For companies faced with incompatible information systems and inconsistent operating practices, ERP has been a dream comes true. ERP presents companies with the opportunity to standardize and automate business processes throughout the organizations, thus increasing productivity and reducing cycle time. Although ERP systems have delivered value, it is becoming clear that the ERP model, which wraps organizational processes into one end-to-end application, may no longer be sufficient for today's fast-moving, extended enterprises. With the rapid growth of the internet, the business environment has changed dramatically. The world has become a global marketplace.

The history if the IS/ICT applied in the Czech companies is very interesting example of the IT evolution because this country is good representative of central European country with high developed manufacturing and automotive industry sector. The history of IS/ICT usage could be divided into following stages.

Please use the following format when citing this chapter:

Josef, B., Jan, P., Eva, S., 2007, in IFIP International Federation for Information Processing, Volume 255, Research and Practical Issues of Enterprise Information Systems II Volume 2, eds. L. Xu, Tjoa A., Chaudhry S. (Boston: Springer), pp. 1311-1318. 


\begin{tabular}{|c|c|c|c|c|}
\hline & $50-60$ 's & $70-80 \div \mathrm{s}$ & $90^{\circ} \mathrm{s}$ & present \\
\hline $\begin{array}{l}\text { Main area of ICT } \\
\text { application }\end{array}$ & $\begin{array}{l}\text { Scientific and } \\
\text { technical } \\
\text { computing }\end{array}$ & $\begin{array}{l}\text { Automation of } \\
\text { product design } \\
\text { and production } \\
\text { planning support }\end{array}$ & $\begin{array}{l}\text { Internal } \\
\text { company's } \\
\text { integration }\end{array}$ & $\begin{array}{l}\text { External } \\
\text { companies } \\
\text { integration with } \\
\text { flexible and } \\
\text { innovative } \\
\text { business } \\
\text { processes }\end{array}$ \\
\hline $\begin{array}{l}\text { Main metrics of } \\
\text { ICT performance }\end{array}$ & Faster computing & Higher production & Higher sale & $\begin{array}{l}\text { Better economical } \\
\text { factors of } \\
\text { company }\end{array}$ \\
\hline
\end{tabular}

Figure 1. Development Stages of IS/ICT in the Czech Republic and Main Metrics of Their Performance

The ICT applications have moved from laboratories and design offices in companies 30 to 40 years ago. Today the notebooks, mobile phones and PDA help to decisions making of managers. The father development continues, thanks to nanoand biotechnologies, to support of health, safety and education. These all are trends declared by European Union in Europe concept i2010 and known under a form of eHealth, eLearning, eSecurity, eGovernment

Applications of enterprise information systems thus have growth recently and they are necessary. It is hardly imaginable to envision the companies without them today. But structures if companies' information system solutions are not simple and the cost for their operation and maintenance has been increasing lately.

\section{ANALYSIS OF ERP MARKET IN THE CZECH REPUBLIC}

Because there is above mentioned shortage of suitable data described data for ICT development and growth it is positive that the authors of this article have analyzed annually the situation of the ICT market on the example of the ERP applications in the Czech Republic since 1993. He has now many data available describing the development of functionality, number of implementations and the tendency to shorten time of implementation of ERP applications as the most significant business applications [1].

The latest survey was undertaken in January 2007 confirms the current situation and partly explains behavior on the ICT market. The first group of results shows a very high penetration of ERP applications. This is much higher than SCM, CRM or $\mathrm{BI}$ application (see illustrative pictures below): 
The Survey of the Main Trends of the ERP Applications in the Czech Republic and their
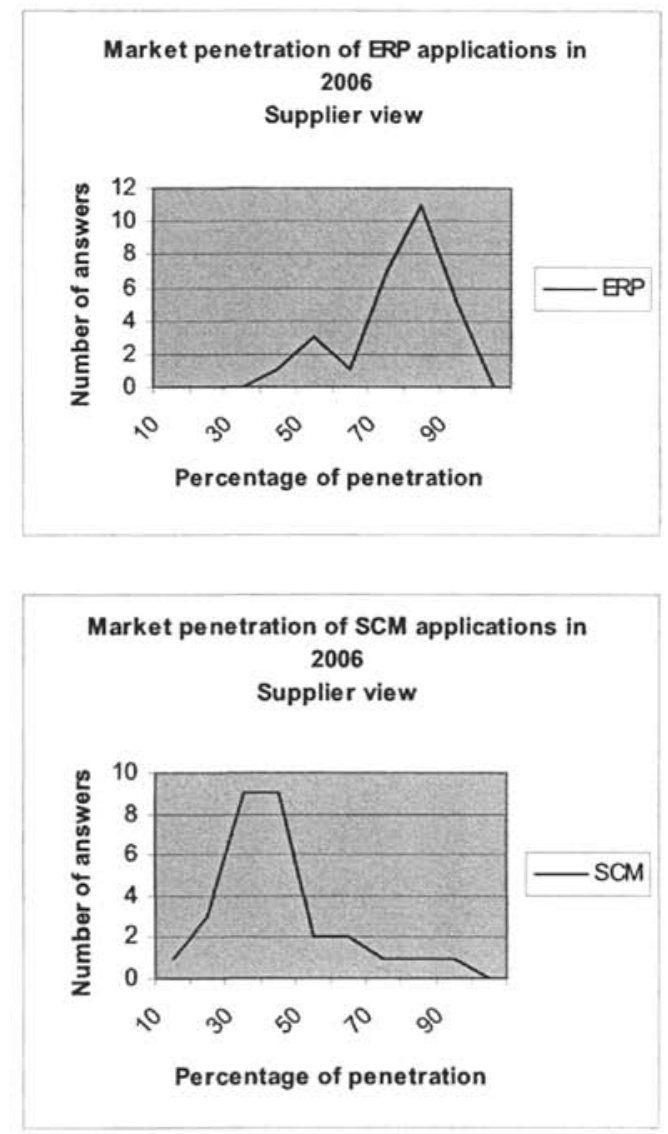

Figure 2. Comparison of Deferent Level of Penetration of Business IS/ICT Applications

It has influence on the behavior of the IS/ICT, if you like ERP, delivering firms. They expect (it means aprox. 60 delivering firms analyzed annually) the high development in years 2006/07 generally. The development is expected not only in new user interface but also new functionality, new algorithm are expected. The ERP systems are very conservative because only 11 percent is expected to innovate significantly. That all will be offered for increasing price for maintenance of IS applications. 


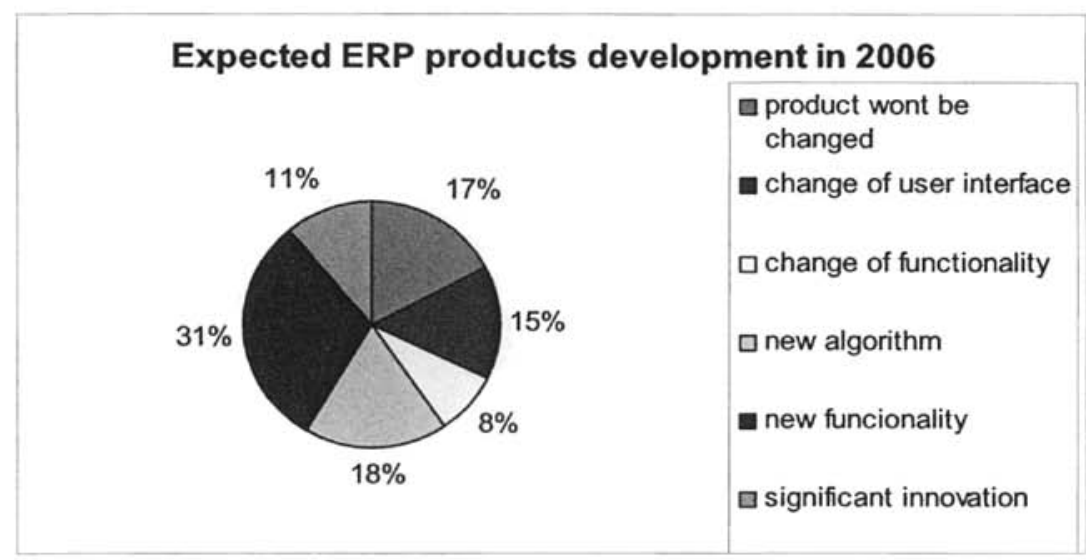

Figure 3.Comparison of Expected ERP Product Development on the Czech Market in 2006

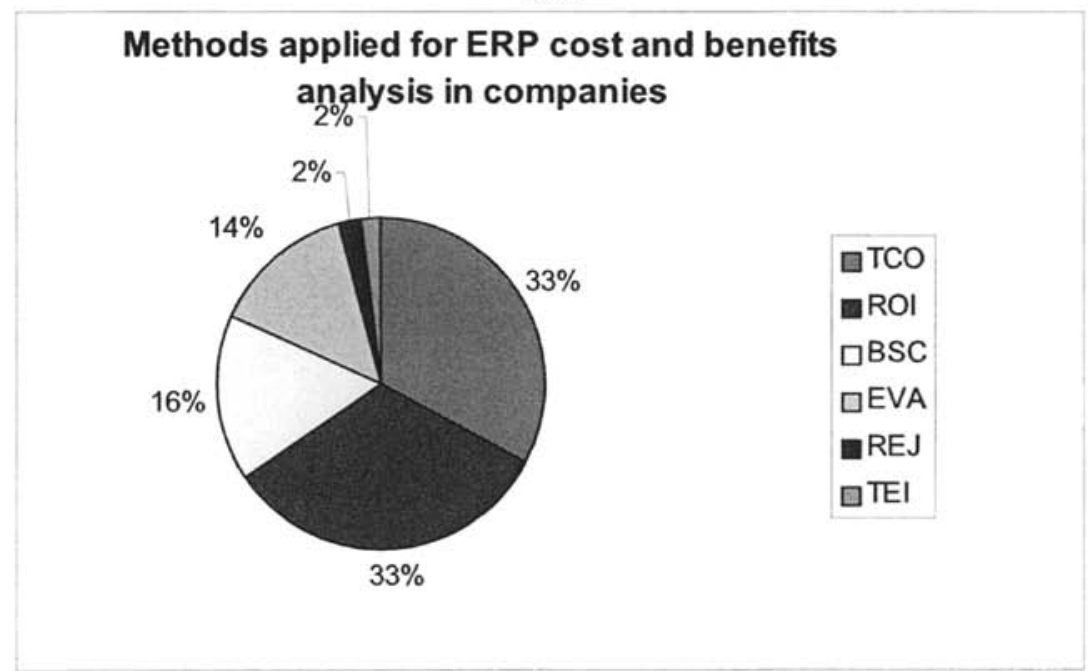

Figure 4. Comparison of Expected ERP Product Development on the Czech Market in 2006

The most applied methods in the Czech companies used for measurement of IS benefits like TCO (Total Cost of Ownership), ROI (Return on Investment), BSC (Balanced Scorecard), EVA (Economic Value Added) are on the following figure. 
The Survey of the Main Trends of the ERP Applications in the Czech Republic and their

Business Effects 1315

\section{ANALYSIS OF BUSINESS EFFECTS OF INFORMATICS}

It means the Czech companies more and more understand the business value of enterprise information systems and use above mentioned methods. The authors of this article also did the pilot inquiries on the quality and effects of enterprise informatics that was undertaken in 2006 within Czech companies [2]. The effect of informatics is in this context understood as any change resulting from application of information services and/or products, e.g. positive development of economic indices, market position of the company, number of new customers, shorter lead time of orders, etc.

Inquiries were concentrated on three groups of respondents: (1) Top managers of companies active on the Czech markets - 18 respondents, (2) Lower levels of management and operation - 33 respondents, and (3) Managers and professionals directly involved in informatics -67 respondents

\subsection{Effects of Informatics by Contents}

There were defined 6 different areas of enterprise economic and other effects connected to the application of informatics. Principal results of the inquiry are presented below - see Fig. 1 .

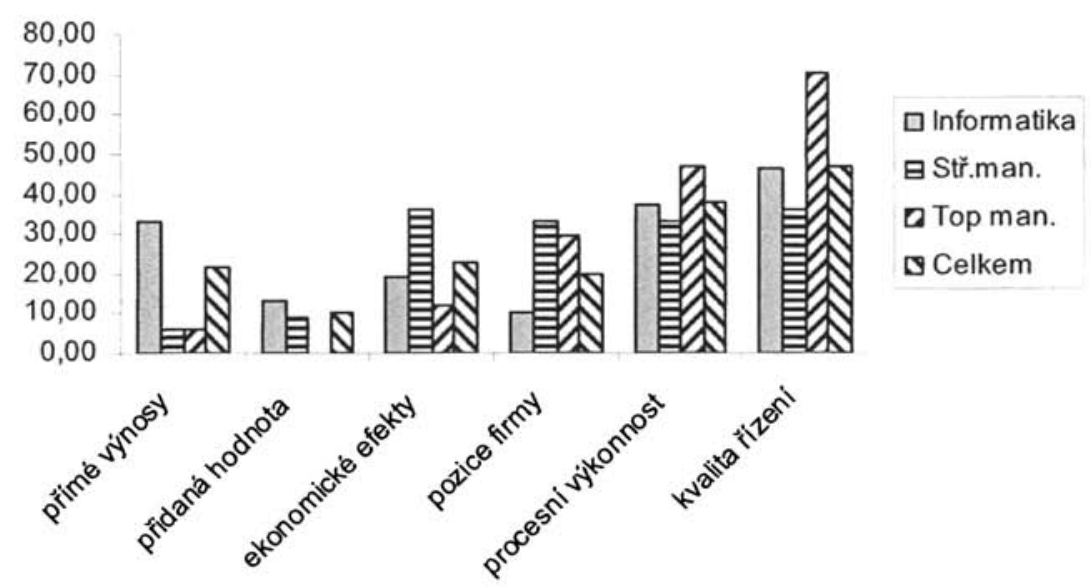

Legend: Direct yield, value added, economic effects, company position, process performance, management quality

Figure 5. Distribution of Informatics Effects by Contents (percentage of respondents)

The results presented indicate that most important effects are due to process performance of the company ( 38 per cent of answers) and to the management quality (47 per cent). As regards the lower managerial level the economic effects are 
mentioned ( 23 per cent). On the other hand, only 10 per cent of respondents consider application of informatics as a value added to the offered products and services, e.g. as a support to project and design activities (building and furniture industries), consultancy services, etc. In this respect, no single positive answer was received from top managers. This might indicate that in some branches (e.g. the food processing industry) the use of informatics is very low, eventually non-existing.

Responses related to improvement of management quality and process performance of company is in general positive and in particular supported by top managers - almost 50 per cent as regards process performance and even 70 per cent concerning the quality increase. This would probably lead to increased demand for projects oriented towards further quality improvement such as business intelligence, workflow management, management of relations with customers etc. In order to obtain significant effects in process performance of enterprises it seems useful to apply comprehensive reengineering projects despite the existing personal and organizational limits. However, the tendencies towards the implementation of new process management technologies (workflow) are evident.

\subsection{Principal Informatics Effects}

Effects of informatics are the key issue assuring the enterprise competitiveness on markets. Fig. 2 below shows the share of different factors influencing the implementation of informatics within the enterprise.

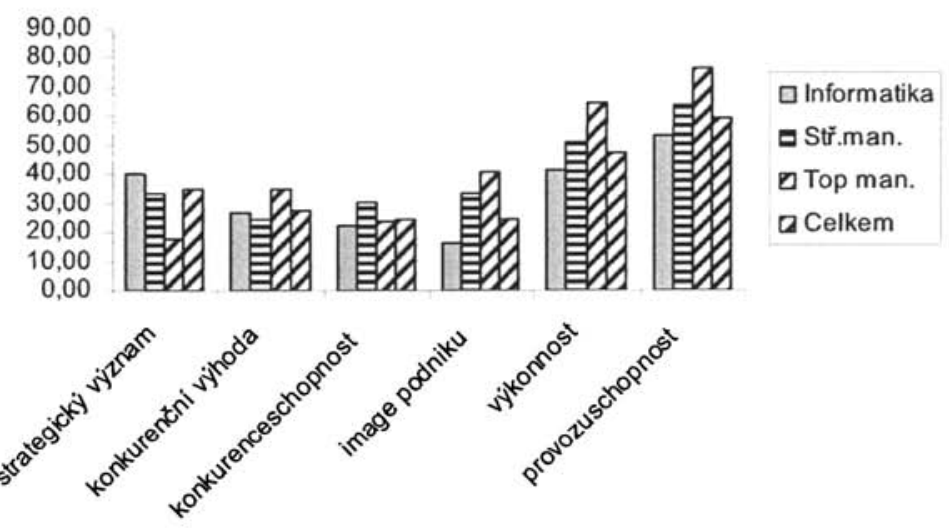

Legend: Strategic importance, competitive advantage, competitiveness, enterprise image, performance, operational ability

Figure 6. Distinction of Factors Influencing Enterprise Informatics (percentage of respondents) 
The Survey of the Main Trends of the ERP Applications in the Czech Republic and their

Majority of respondents (in all three categories) underlined the importance of enterprise operational activities, including accounting and other financial operations, trading operations, etc. The group of top managers provided in this respect almost 80 per cent of positive answers. Similar trends were registered as regards the total enterprise performance - process, management and analytical performance. While relatively high number of managers positively evaluated the effect on enterprise image - 14 per cent of top managers and 33 per cent of lower management level the informatics professionals allocated to imaging only 16 per cent share.

Most interesting seems to be managerial viewpoint regarding the role of informatics in increasing the enterprise competitiveness. Positive answers in this respect were around 25 per cent (almost 35 per cent of top managers). On the other hand, strategic importance of informatics received around 20 per cent of positive answers. Informatics is believed to be the driving force of enterprise competitiveness - in this respect the number of positive responses received in 2006 however since last inquiries undertaken several years ago continuously growing seems still rather low. Further development of information and communication technologies and higher qualification of managers in general is expected to bring positive changes.

\subsection{Planning of Informatics Effects}

Quality of informatics depends on the planning methods selected for the project design and implementation. Only some 18 per cent of managers confirmed systematic and regular planning, while 35 per cent of responses proved that planning was closely connected to the start of a new project. On the other hand, almost 17 per cent of respondents declared that enterprise planning of effects was more or less a random process. For more details see Figure 7 below.

Planning of application effects since the beginning of project specification and if possible the use of standard project methodologies would assure the final success. In this respect the responses of informatics professionals are more optimistic -40 per cent of respondents declared that their enterprises adopted systematic and forward planning methods, while only 6 per cent of enterprises still continued with random approaches.

\section{CONCLUSIONS}

The inquiry undertaken proved that most of the Czech enterprises prefer a systematic planning and evaluation of informatics projects. This is also the way to decrease high costs of information and communication technologies (ICT) as well as of the further development and operation of information systems, and efforts needed for proliferation of informatics in the overall management. Analysis and planning of ICT effects became an integral part of the innovation life cycle. Management system of the enterprise (strategy, forecasting, various types of planning, managing of company activities) should be closely integrated with the informatics management 
(from information strategy to the reliable operation of individual tasks and applications).

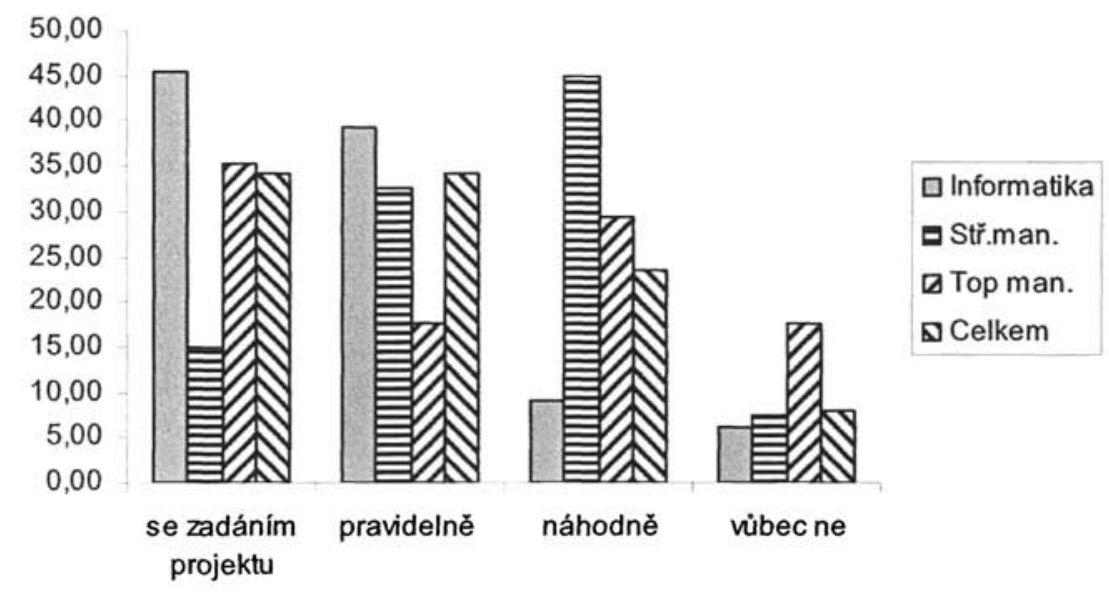

Legend: Part of project documentation, regular, random, none

Figure 7. Approaches to Planning of Informatics Effects (percentage of responses)

\section{REFERENCES}

1. J. Basl, Enterprise Information Systems - Annual Survey of the ERP Market Offer in the Czech Republic, Businessworld (Prague, 2001-2006).

2. J. Basl and J. Pour, Enterprise Informatics Quality in the Information Society Context, Working Paper CES VŠEM Number 10 (Prague, 2006).www.vsem.cz 